\title{
Vontade de tragédia, tragédia da música: Controvérsias entre o jovem Nietzsche e Schopenhauer
}

\author{
Gabriel Debatin*,**
}

\begin{abstract}
Resumo: O presente ensaio tem como objetivo mostrar consequências teóricas de uma tensão latente entre a noção de tragédia no Nietzsche d'O nascimento da tragédia e a compreensão schopenhaueriana da música. Tal tensão se dá não apenas no âmbito de interpretações estéticas das referidas artes por parte dos filósofos mencionados, mas demonstra disparidades fundamentais no pensamento do jovem Nietzsche em relação à metafísica de O mundo como Vontade e Representação. A hipótese é que essas disparidades culminariam num ponto de cesura entre as filosofias de Schopenhauer e Nietzsche, bem como no fenecimento da amizade deste com Richard Wagner.
\end{abstract}

Palavras-chave: Tragédia, Música, Vontade, Nietzsche, Schopenhauer, Wagner.

\footnotetext{
* Professor do Departamento de Ciências Humanas da Universidade Tecnológica Federal do Paraná, Pato Branco, PR, Brasil.

**Doutorando em Filosofia pela Universidade Federal de Santa Catarina, Florianópolis, SC, Brasil. ORCID https://orcid.org/0000-0003-1139-0115

Correio eletrônico: gabrieldebatin@gmail.com
} 
Vontade de tragédia, tragédia da música: Controvérsias entre...

Embora seja um texto precoce, $O$ nascimento da tragédia segundo o espírito da música, de 1872, revela diversos temas cruciais para toda a produção filosófica madura de Nietzsche. A nítida influência do pensamento de Schopenhauer neste texto, em específico, é preponderante para a formação da metafísica nietzschiana, fundamentada na Vontade como determinação geral do ente, conceito que posteriormente se delimitará em Vontade de Potência [Wille zur Macht]; tal processo, ou ao menos sua gênese, pretende-se abordar no presente ensaio. É certo que se trata de um tema repleto de distintas e conflitantes interpretações - assim como qualquer ponto da filosofia nietzschiana, que sempre se demonstrou essencialmente polêmica, nunca consensual. É de bom tom, portanto, a fim de conferir ao ensaio maior precisão e delimitação metodológica, ressaltar que o viés interpretativo que guia o presente texto no tocante à filosofia de Nietzsche, compreendida como um todo, mas aqui referindo-se especialmente à sua fase mais madura é aquele que a lê como uma metafísica, centrada no conceito de Vontade de Potência, o qual opera como chave hermenêutica fundamental, tanto para a economia de seu pensamento, quanto para o que compete ao modo como se dá o mundo e a humanidade em nossa época - portanto, ontologicamente; enquanto fundamento metafísico do mundo - um fundamento, por decerto, bastante sui generis, porque essencialmente mutável devido sua natureza transvalorante de valores -, o conceito de Vontade de Potência manifesta a essência não só da vida, como tenderia a crer a corrente de interpretação nietzschiana dita "vitalista" - cujos principais representantes são indubitavelmente os franceses (Deleuze, Blossowski, Bergson, Bataille e em certo sentido também Foucault) -, ${ }^{1}$ mas como uma força motriz que extrapola os limites da vida e efetivamente espalha sua malha de poder por sobre tudo o que há, apontando Nietzsche como o grande e legítimo metafísico de nossa época. Entretanto, não se trata de longamente dissertar

1 Gianni Vattimo, 2010, p. 136-137. 
Debatin, G.

aqui sobre a natureza da Vontade de Potência como tal, mas, como dito, de lançar o olhar sobre seu despontar latente em $O$ nascimento da tragédia, onde é evidente a influência do sistema metafísico de Schopenhauer. ${ }^{2}$ Tal influência, que ecoará em toda a futura produção nietzschiana, consagrando-o como crítico cultural e filosófico, aparece, aqui, neste referido texto de 1872, através da presença originária de um tema mítico - embora vertido à filologia e à filosofia -, apontando precisamente a Dioniso e Apolo.

Em relação às imagens apolíneas e dionisíacas, e com elas a uma característica abordagem da tragédia, tematiza-se por Nietzsche o problema da origem, questão preponderante para aqueles que pretendem trilhar o método genealógico. É fato que a genealogia nietzschiana se desenvolveu mirando a procedência dos juízos de valor que foram se obnubilando no decurso da história e perdendo seu sentido original. É neste sentido que se fala de "origem" no presente texto: não como uma tentativa (clássica) de se retornar às fontes primordiais dos conceitos, numa atitude essencialista, mas, pelo contrário, em acordo com o nexo da filosofia de Nietzsche, de demonstrar o esvaziamento de sentido que subjaz aos conceitos pétreos da tradição. Neste ínterim, o método genealógico se remete sempre duplamente à origem: uma origem "mais de princípio", que conteria o sentido primevo do objeto investigado, o qual é oculto pela segunda origem: a origem do equívoco, o momento em que a verdade da coisa é encoberta por uma falsa ou inapropriada determinação sua, a qual se põe no lugar do propriamente verdadeiro e origina um novo fundamento, decadente e controverso. Todavia, essa dupla

2 Tal influência é inconteste, dadas as inúmeras recorrências que Nietzsche efetua a Schopenhauer ao longo do texto, valendo-se com grande fidelidade da metafísica de $O$ Mundo como Vontade e Representação. A título de bom exemplo se pode citar Rosa Maria Dias, 1997, pp. 07-21. Tal texto possui, inclusive, intento similar ao aqui ora apresentado, percorrendo, porém, um caminho ligeiramente diverso: dá mais peso à filosofia de Schopenhauer propriamente dita, mostrando sua influência no texto nietzschiano, enquanto aqui pretendemos dar mais enfoque a Nietzsche mesmo, acenando às disparidades de seu conceito de Vontade com o de Schopenhauer, as quais se dão via sutis discrepâncias na tematização do trágico e da música.

126 | Cad. Nietzsche, Guarulhos/Porto Seguro, v.40, n.2, p. 124-145, maio/agosto, 2019. 
referência à origem empenhada pela genealogia nietzschiana se mostra variável, a depender da fase de produção do filósofo, não sendo constatável de per legem nos textos posteriores a $O$ nascimento da tragédia, textos tais que não são necessariamente mais maduros, como em Sobre verdade e mentira no sentido extramoral, de 1873, em que Nietzsche se refere apenas à origem da décadence, como se o mundo e a existência já tivessem surgido em declínio; contudo, parece necessário concluir que, se há um declinar, não é possível negar que haja também uma condição original que então se vai corrompendo. Tal condição, vale ressaltar, não está ainda enquadrada no proceder genealógico em termos de juízos de valor nestes seus textos mais de juventude, como se dará de modo mais evidente nos textos mais maduros de sua produção filosófica.

Contudo, em $O$ nascimento da tragédia segundo o espírito da música essa dupla referência à origem é manifestada de modo muito claro: conforme acusa o próprio título da obra - cujos termos "nascimento da tragédia" e "espírito da música", inclusive, remontam a noções originalmente wagnerianas,$-^{3}$ o texto procura apontar a música como origem da tragédia. Se seu nascimento se deu devido à música, sua causa mortis foi por decerto o afastamento de sua origem: sua derrocada se deve, segundo Nietzsche, à aproximação da arte trágica à maximamente apolínea filosofia socrática, onde o dionisíaco é condenado, a música, esquecida, a origem, desprezada. No caso da tragédia, sua origem mais de princípio, segundo Nietzsche, remete-se à música. A origem de sua decadência, por sua vez, à

\footnotetext{
3 A própria expressão "nascimento da tragédia" é de autoria não de Nietzsche, mas antes de Wagner, segundo o qual apenas graças à junção das artes efetuada pelos gregos, que gerou o que ele chama de novas formas de poesia [neue Formen der Dichtung], foi tornado possível o nascimento da tragédia [die Tragödie geboren werden konnte]. Cf. Richard Wagner, 1850, p. 122. Wagner também recorre várias vezes em seu ensaio $A$ obra de arte do futuro à noção de espírito [Geist], aplicando-a às mais diversas artes, sendo ausente, contudo, a expressão "espírito da música"; a noção mais próxima encontrada no referido texto é a de geistig dichtende Wort, "a palavra espiritualmente poética", cujo tom, à medida que vai se distanciando da mera palavra, vai desenvolvendo a harmonia [der Harmonie] propícia à música absoluta [der absoluten Musik]. Cf. Ibid., p. 75-76. A expressão "espírito da música" aparece, contudo, várias vezes em seu mui célebre Beethoven, de 1870. Cf. Id., 1870, passim.
} 
Debatin, G.

filosofia. No aproximar-se da arte trágica à ciência filosófica, algo se perdeu, algo de dionisíaco. Tal corrupção se deve à apolinização do elemento dionisíaco da tragédia, que, embora sendo essencialmente formada tanto pela plasticidade apolínea, quanto pela embriaguez dionisíaca, cabe a esta última a preponderância na arte trágica, seu surgimento e manutenção. Na apolinização filosófica da tragédia, a música ditirâmbica sucumbiu, como sabido, dado ter-se aproximado da beleza harmoniosa de Apolo e se afastado da vontade impetuosa de Dioniso. Não obstante, entende-se aqui a aproximação de Nietzsche a Schopenhauer e a Wagner em $O$ nascimento da tragédia, uma vez que para os três a música é expressão imediata da Vontade universal, essência do mundo, manifestando o cerne metafísico de seus pensamentos; contudo, embora a base teórica fundamental para tal caracterização da música e da arte trágica esteja em Schopenhauer, cabe ressaltar que não só Nietzsche, mas também Wagner a reveste com suas inegáveis particularidades. ${ }^{4}$ A originalidade de Nietzsche não se encontra, portanto, em pensar a música como expressão direta da Vontade, mas em pensar a música como origem da tragédia, tanto em sua clássica expressão helênica, quanto em seu anseio por um renascimento da arte trágica na Alemanha moderna, numa tentativa, posteriormente abandonada, de legitimar Richard Wagner como o novo tragediógrafo, um novo Ésquilo.

Na qualidade de expressão imediata da Vontade, a música, em seu espírito, isto é, no clima volitivo proporcionado pelo arrebatamento dionisíaco, é capaz de originar o mito trágico, o qual se estabelece, na consideração nietzschiana, através de uma espécie de dialética entre vontade e beleza, entre universalização e individuação, entre embriaguez e comedimento, enfim, entre Dioniso e Apolo. "Devemos entender a tragédia grega como o coro dionisíaco, que a cada vez se

4 Cf. Roberto Machado, 2005, p. 178. Como não compete propriamente ao escopo do presente ensaio dissertar sobre a muito importante recorrência de Wagner a Schopenhauer, bem como a originalidade teórica daquele em relação a este, confira-se sobretudo: Henry Burnett, 2009, p. 160ss; Luan Corrêa da Silva, 2012, p. 212ss; Márcio Benchimol Barros, 2012, p. 180ss.

128 | Cad. Nietzsche, Guarulhos/Porto Seguro, v.40, n.2, p. 124-145, maio/agosto, 2019. 
Vontade de tragédia, tragédia da música: Controvérsias entre...

descarrega novamente num mundo de imagens apolíneo" (GT/NT, O nascimento da tragédia $8, \mathrm{KSA} 1.59$ ). A questão da arte trágica só pode ser concebida, portanto, quando pensada em sua dualidade antitética, como manifestação simultaneamente apolínea e dionisíaca. Cito Nietzsche:

Em oposição a todos os que se esforçam para derivar as artes de um único princípio, que é tido como uma necessária fonte de vida para qualquer obra de arte, eu detenho o olhar nas duas divindades artísticas dos gregos, Apolo e Dioniso, e marcadamente os reconheço como os representantes vivos e nítidos de dois mundos artísticos diferentes em sua mais profunda essência, assim como em suas mais altas ambições (GT/NT, O nascimento da tragédia 16, KSA 1.103).

Na concepção de Nietzsche, toda arte imagética, sendo regida pelas formas, é apolínea, enquanto a música, sendo amorfa - ao menos de imagens, plasticamente -, é essencialmente dionisíaca. Deriva filosoficamente essa constatação de Schopenhauer, para quem a música não é um reflexo dos fenômenos, $\mu$ ínךбıৎ da coisa, mas, pelo contrário, reflexo imediato da Vontade, e, por isso, representa "para tudo que, no mundo, é físico, o metafísico, e para todo o fenômeno, a coisa em si" (O Mundo como Vontade e Representação, I, p. 310). ${ }^{5}$ Nietzsche menciona, nesse ínterim, o jovem Wagner, que descobriu que a música deve ser medida de acordo com princípios estéticos distintos das demais artes, portanto, não tendo o belo como pedra-de-toque, mas como excitação dos sentimentos e sensações, efervescência da Vontade. Logo, julga errônea a concepção estética que procura exigir da música o estímulo do agrado através das belas formas, em termos schopenhauerianos, da representação, como se dá nas artes figurativas - concepção que, segundo Nietzsche, a música e os ensaios do Wagner tardio trairão, culminando no rompimento de sua amizade. Consequentemente, se a tragédia possui sua origem de

5 Arthur Schopenhauer, 2005, p. 345.

Cad. Nietzsche, Guarulhos/Porto Seguro, v.40, n.2, p. 124-145, maio/agosto, 2019. 
Debatin, G.

acordo com o espírito da música, e esta, sendo expressão imediata da Vontade, não do belo, não serve a estética clássica, como Nietzsche se referiria, como meio de avaliação da arte trágica. Neste tocante, a filosofia da arte nietzschiana se afasta radicalmente da tradição, iniciada na Poética de Aristóteles e desenvolvida até o romantismo alemão - embora seja indiscutível o fato de que Friedrich Schlegel também exerce notória influência sobre o referido texto de Nietzsche. ${ }^{6}$ O elemento trágico, portanto, não é derivável da essência da arte, se esta for concebida de acordo com a categoria da aparência e da beleza. Isso não quer dizer, todavia, que não haja na arte um acontecimento do belo: ora, é filha não só de Dioniso, mas também de Apolo, e, sob as bênçãos desta divindade, produz um prazer na aparência que não deve ser negado.

Embora filha de dois pais, a música, e a partir dela o mito trágico, versa sobre um conhecimento dionisíaco, que assume preponderância em relação à forma apolínea. "A arte dionisíaca também quer que nos convençamos da eterna luxúria da existência [Daseins]: só que não devemos procurar essa luxúria nas aparências, mas sim atrás delas" (GT/NT O nascimento da tragédia 17, KSA 1.109). O que Nietzsche chama de "nova música ditirâmbica", aquela música já contaminada pela influência socrática, dessitua a música de sua essência criativa, conforme a Vontade, e a insere num nexo pictórico, que meramente relata situações quotidianas. É por isso que Eurípides é adepto dessa "nova música", que já não canta mais sobre os grandes heróis, mas através da qual o homem comum é conduzido às honras do palco, narrando com uma "fidelidade vergonhosa que também reproduz escrupulosamente as mal traçadas linhas da natureza" (GT/NT O nascimento da tragédia 11, KSA 1.76). Sendo refém da descrição do real - schopenhauerianamente digamos, da representação - e, portanto, não fiel à Vontade, Eurípides se

6 Cf. a respeito da marcante presença do pensamento de Friedrich Schlegel - bem como de seu irmão, August Schlegel - na consideração nietzschiana da arte trágica, Ernst Behler, 1978, p. 71-77.

$130 \mid$ Cad. Nietzsche, Guarulhos/Porto Seguro, v.40, n.2, p. 124-145, maio/agosto, 2019. 
Vontade de tragédia, tragédia da música: Controvérsias entre...

demonstra de uma natureza inteiramente não musical, e, não sendo mais afim ao espírito da música, sua tragédia não é mais autêntica.

Em toda a caracterização teórica conferida por Nietzsche à música e à tragédia, é fidedigna sua recorrência à metafísica schopenhaueriana. Ao contrário do que afirma Szondi no seu Ensaio sobre o trágico, a saber, que "no ponto decisivo [em $O$ nascimento da tragédia] o modelo de Schopenhauer aparece apenas como algo negativo", 7 em nossa perspectiva se dá exatamente o oposto: o sistema filosófico-metafísico que sustenta tanto a caracterização nietzschiana da música e correlatamente da tragédia, quanto sua crítica à música e à arte moderna é sempre o sistema schopenhaueriano. A afirmação de Szondi, é claro, não é de todo descabida, uma vez que seu interesse não é a metafísica nietzscheina, mas sua caracterização da tragédia - onde Nietzsche, de fato, demonstra notória originalidade filosófica. No cerne teórico de $O$ nascimento da tragédia, contudo, vigora Schopenhauer, ainda maximamente influente no jovem Nietzsche, que ora publica seu primeiro texto. Salvo minúcias que diferem a aplicação nietzschiana do conceito de Vontade da schopenhaueriana, minúcias tais que posteriormente se especificarão e aprimorarão o conceito de Vontade em Vontade de Potência - e que serão tratadas na sequência -, o Nietzsche d'O nascimento da tragédia segundo o espírito da música permanece adepto à metafísica de Schopenhauer, fato confesso, inclusive pelo Nietzsche tardio, como demonstra a reedição de 1888, que reentitula o texto para $O$ Nascimento da Tragédia, ou Helenismo e Pessimismo e critica sua adesão a Schopenhauer. ${ }^{8}$ As diferentes concepções do trágico entre ambos, dessarte, são ressaltadas pelo Nietzsche maduro: com efeito, afirma, na Tentativa de Autocrítica publicada nesta reedição, que sua caracterização da vontade dionisíaca se opõe à resignação da Vontade que se dá

7 Peter Szondi, 2004, p. 67.

8 É interessante notar que este novo título suprime, certamente de modo intencional, a expressão "espírito da música", de viés absolutamente wagneriano, como já apontado. 
Debatin, G.

no trágico, como pensava Schopenhauer (Cf. GT/NT Tentativa de Autocrítica 6, KSA 1.19-20).

Este fato, porém, passou despercebido n'O nascimento $d a$ tragédia tal como foi inicialmente concebido. No décimo sexto capítulo do texto, Nietzsche chega a citar duas páginas inteiras de $O$ Mundo como Vontade e Representação, trecho em que Schopenhauer afirma a música como expressão da Vontade no mundo. Chama, contudo, a atenção, o fato de Nietzsche se referir a uma passagem manifestamente idealista de Schopenhauer, onde este assevera que a música é meio de acesso privilegiado às formas. Escreve o pessimista:

A música nunca expressa o fenômeno, mas unicamente a essência íntima, o em-si de todos eles, a Vontade mesma. A música exprime, portanto, não esta ou aquela alegria singular e determinada, esta ou aquela aflição, ou dor, ou espanto, ou júbilo, ou regozijo, ou tranquilidade de ânimo, mas eles mesmos, isto é, a Alegria, a Aflição, a Dor, o Espanto, o Júbilo, o Regozijo, a Tranquilidade de Ânimo, em certa medida in abstracto, o essencial deles, sem acessórios, portanto também sem os seus motivos. E no entanto a compreendemos perfeitamente nesta quintessência purificada. ( $O$ Mundo como Vontade e Representação, I, p. 308-309). ${ }^{9}$

A música é caracterizada por Schopenhauer como uma linguagem universal que expressa a própria verdade do mundo, quase como o vooú $\mu \varepsilon v o v$ platônico - à exceção de, ao contrário deste, ser a música, em certo sentido, uma linguagem -; o trecho citado por Nietzsche, inclusive, assemelha a música às figuras geométricas e aos números, sendo todos "formas universais de todos os objetos passíveis de experiência", ${ }^{10}$ numa estranha semelhança com a aproximação de Platão à música, que no Livro VII da República chega a aparentar o matemático e o geômetra ao músico (República, 525a-531d). ${ }^{11}$

9 SCHOPENHAUER, 2005, p. 343. [Grifo do autor].

10 Ibid., p. 344.

11 Platão, 1965, p. 120-131.

132 | Cad. Nietzsche, Guarulhos/Porto Seguro, v.40, n.2, p. 124-145, maio/agosto, 2019. 
Interessante notar ainda que, no Crátilo (406a), Platão sustenta que o termo "música" possui a mesma origem que "musa", a saber, $\mu \tilde{\omega} \sigma \theta \alpha 1$, querer algo, desejar, "denominação derivada da pesquisa e do amor à sabedoria [filosofia]". ${ }^{12}$ Essa correspondência entre música e Vontade, e, em maior grau, num nível essencialista-idealista, é curiosa em se tratando de uma referência a Nietzsche, dada a conhecida ojeriza nutrida por este da filosofia socrático-platônica, e, consequentemente, do idealismo, quer tido como sistema, quer como visão de mundo. Manifesta, assim, certa contradição na posição assumida por Nietzsche, que, ao mesmo tempo em que atribui a Sócrates/Platão a causa mortis da tragédia, caracteriza-a teoricamente recorrendo a uma argumentação derivada de seu antagonista. ${ }^{13}$

Em retomada, a música, para Schopenhauer, é a mais sublime das manifestações artísticas porque é a única que tem a capacidade de causar no expectador uma espécie de insight que acessa a Vontade de modo puro, sintonizando o fruidor com a própria essência metafísica do mundo. Explica o filósofo:

A íntima referência da música à essência verdadeira de todas as coisas explica o fato de que, quando soa uma música que combina com uma cena, ação, acontecimento, cercania, como que se nos revela o sentido mais misterioso dos mesmos, entrando em cena como o comentário mais correto e distinto deles. De maneira similar, quando alguém se entrega por inteiro à impressão de uma sinfonia, é como se visse desfilar diante de si todos os eventos possíveis da vida e do mundo; contudo, se medita, não pode fornecer semelhança alguma entre aquela peça musical e as coisas que passavam diante de si. Pois a música é diferente de todas as outras

12 Id., 1988, p. 132. Cf. também, Henry George Lidell \& Robert Scott, 1869, p. 968; 1034.

13 É pertinente notar que o recurso idealista adotado por Schopenhauer está ligado sobretudo a Platão e Kant. À discordância do primeiro, julga serem as Ideias não-racionais, além-lógicas, bem como não constituírem o patamar mais elevado em se tratando de uma gradação conceitual metafísica sobre a essência do real, estando submetidas à Vontade, da qual se manifestam como objetivação no mundo fenomênico. Por outro lado, aproxima-se de Kant ao pensar as Ideias como intuições que por natureza fogem da articulação em forma de conceitos, ou, em seus termos, de representação [Cf. Arthur Schopenhauer, 2003, p. 229-230]. 
Debatin, G.

artes por ser não cópia do fenômeno, ou, mais exatamente, da objetidade adequada da Vontade, mas cópia imediata da Vontade e, portanto, expõe para todo o físico, o metafísico, e para todo o fenômeno, a coisa-em-si $(O$ Mundo como Vontade e Representação, I, p. 310). ${ }^{14}$

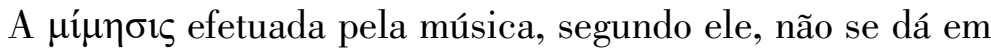
relação aos fenômenos ou aos entes sensíveis, como pensava Platão, do que decorre o fato de julgar que as artes em geral possuem uma conotação ontologicamente inferior em relação à filosofia, que, ao contrário, é capaz de acessar as Ideias. Schopenhauer inverte a relação: é muito mais apropriado acessar as Ideias via manifestações da Vontade do que via representação - onde se enquadraria toda a especulação filosófico-conceitual. A $\mu$ í $\sigma ı \varsigma$ efetuada pela música, superior a qualquer argumento, é imitação da espécie de alémvooú $\varepsilon_{\varepsilon v o v}$ que é a Vontade. Em oposição aos fenômenos, que são sempre passíveis de descrição e demonstração, a Vontade não é racional e, logo, também não é linguística, pelo que a relação que a música desempenha em correspondência com a Vontade pode ser explanada, mas nunca comprovada, não restando aquém do conhecido domínio da lógica. Com efeito, na Metafísica do Belo, Schopenhauer defende que o poder metafísico da música, por conta do exposto, só pode ser compreendido pela fruição estética, especificamente, pelo ato de apreciação musical, num movimento de simultânea experiência e comprovação da tese. ${ }^{15}$

Como bem percebeu Szondi, "dionisíaco" e "apolíneo" em Nietzsche aparentam mui bem corresponder a "Vontade" e "representação" em Schopenhauer, respectivamente. ${ }^{16}$ Ora, enquanto Dioniso é aquele que, através do êxtase, da embriaguez e dos delírios, inspira os sátiros em seu canto, o qual origina da livre Vontade

14. Schopenhauer, 2005, p. 344-345.

15 Cf. Id., 2003, p. 228-229.

16 Cf. Peter Szondi, 2004, p. 67.

134| Cad. Nietzsche, Guarulhos/Porto Seguro, v.40, n.2, p. 124-145, maio/agosto, 2019. 
Vontade de tragédia, tragédia da música: Controvérsias entre...

a tragédia, Apolo, deus da beleza e da razão, inspira os artistas figurativos e os filósofos, aqueles que continuamente versam sobre o mundo como representação, e portanto como calculável, descritível e demonstrável. A originalidade de Nietzsche em relação ao conteúdo conceitual das noções de "dionisíaco" e "apolíneo", não é, portanto, absoluta, mas apenas parcial. Todavia, é crucial notar que, embora Schopenhauer tenha pensado os conceitos de Vontade e representação antes de Nietzsche, não os aplicou à arte trágica exatamente a exemplo deste.

De acordo com a filosofia schopenhaueriana, num ponto em que concordaria Nietzsche, a Vontade é a força originante da tragédia. Porém, em contraste diametral com o pensamento nietzschiano, Schopenhauer entende o drama trágico como forma exemplar da poesia - e não da música -, o qual manifesta a Vontade ao mesmo tempo em que a nega. A arte trágica revela "o lado terrível da vida", ${ }^{17}$ o sofrimento inerente à existência humana, $\mathrm{o}$ qual se deve inteiramente à Vontade. Esta, através da narrativa trágica, é, portanto, objetivada, mas também negada, num processo que Schopenhauer chama de autossupressão (Selbstaufhebung), ou resignação. Ora, à medida em que o herói trágico manifesta a essência da existência humana, o sofrimento, que é fruto da Vontade, ele procura renunciar sua condição, negando-se a si e a Vontade, coisa que, sendo certamente impossível, faz com que o herói trágico se frustre continuamente, maximizando seu sofrimento às últimas potências. Cito Schopenhauer:

Vemos na maior parte das tragédias o herói fazer, ao fim, a transição do querer mais veemente e do esforço violento para a resignação, isto é, para o não-querer total, visto que mediante de todo o sofrimento padecido surge-lhe um conhecimento novo, uma visão nova da existência. Por fim, no ponto em que o sofrimento atingiu seu ápice, ocorre a ruptura [ou cesura]. Porém, na tragédia [...] é indicada ao expectador a resignação durante toda a exposição, e ele é instado a renunciar ao querer num mundo tão terrível

17 Arthur Schopenhauer, 2003, p. 221. 
Debatin, G.

que, assim, de certa maneira tem por regente o acaso, o erro, a maldade; toda a exposição trágica é para o expectador um chamado à resignação, à negação livre da Vontade de vida. ${ }^{18}$

A esta sutileza do dar-se da Vontade na arte trágica Nietzsche se contrapõe, demonstrando sua emancipação de Schopenhauer em vista da formação do conceito de Vontade de Potência. Em desacordo, portanto, com o pensamento schopenhaueriano, a filologia nietzschiana vê a música, não a poesia, como a verdadeira origem da tragédia. Tomando emprestado de Schopenhauer a caracterização da música como forma artística metafisicamente superior, que reflete diretamente a Vontade, Nietzsche a aplica à arte trágica, ponto decisivo no processo de sua independência teórica do filósofo pessimista. Em oposição a este, Nietzsche vê a tragédia a partir de uma perspectiva positiva - para não ousar dizer "otimista" -, sendo ela capaz de justificar esteticamente o mundo e a existência. É apenas devido ao caráter redentor da arte trágica que o jovem Nietzsche anseia por seu renascimento, contravindo totalmente a perspectiva schopenhaueriana de afirmação e negação da Vontade, que proporciona irremediavelmente uma autossupressão sua (Cf. GT/NT O nascimento da tragédia 17, KSA 1.110-111).

Eis aqui uma das principais divergências da aplicação do conceito de Vontade entre Schopenhauer e Nietzsche: enquanto para aquele a tragédia manifesta uma autossupressão da Vontade, ou seja, uma dialética de afirmação e negação desta, que então se anula no drama trágico, a dialética da tragédia em Nietzsche compreende a presença originante do dionisíaco e a presença declinante do apolíneo. Em termos schopenhauerianos, Nietzsche lê a tragédia como pura conjugação de Vontade e representação, associação que Schopenhauer não efetua em sua abordagem específica da arte trágica. Todavia, o filósofo pessimista julga que as belas-artes em geral são constituídas

18 Ibid., p. 221. [Colchetes nossos].

$136 \mid$ Cad. Nietzsche, Guarulhos/Porto Seguro, v.40, n.2, p. 124-145, maio/agosto, 2019. 
por uma unicidade entre Vontade e representação, porque, embora as formas artísticas sejam, em diferentes graus, cópias da própria Vontade, seu palco de atuação, seu âmbito de eficácia se dá no sujeito via representação, no por ele chamado "sujeito entendedor". É válido, portanto, dizer que as artes seriam, em diferentes níveis de perfeição, imitação da universalidade da Vontade, efetuadas sempre via a particularização da representação. ${ }^{19} \mathrm{Ora}$, se todas as artes são constituídas por Vontade e representação, e, considerando que a tragédia é inegavelmente uma arte, logo, também a tragédia é constituída por Vontade e representação. Embora Schopenhauer, em sua análise da tragédia, não tenha efetuado expressamente a relação da arte trágica com os conceitos de Vontade e representação, ele $o$ fez com as artes em geral, pelo que a caracterização da tragédia como constituída tanto como Vontade, quanto como representação pode ser concluída sem muitos esforços da sua análise das belas-artes, às quais obviamente pertence. Essa conclusão lógica, quase que silogística, das premissas de Schopenhauer resume o cerne teórico da concepção do trágico no Nietzsche d'O nascimento da tragédia.

Porém, se os conceitos de apolíneo e dionisíaco não refletem imediatamente a originalidade da produção teórica de Nietzsche, a aplicação desses conceitos à arte trágica, associada primeiramente à música, e não à poesia, somada a esta abordagem ligeiramente distinta da noção de Vontade, criam um cenário outro que o schopenhaueriano, conduzindo a discussão a conclusões por inteiro diversas.

Assim o apolíneo nos resgata da universalidade dionisíaca e nos faz deleitar com os indivíduos; põe neles os nossos comovidos sentimentos de simpatia, e com eles satisfaz nosso senso de beleza, sedento de formas grandes e sublimes; apresenta-nos imagens de vida e, com o pensamento, compelenos a apreender o núcleo vital contido nelas (GT/NT $O$ nascimento da tragédia 21, KSA 1.137).

19 Cf. Günter Zöller, 2010, p. 75-76. Cf. também Rosa Maria Dias, 1997, p. 15-16. 
Debatin, G.

Schopenhauer, devido sua caracterização autossupressora da Vontade pela arte trágica, não está interessado em um renascimento seu, preferindo como expressão artística a ópera - sobretudo a de Rossini. Já Nietzsche, que vislumbra a Vontade expressa na tragédia como redentora, ansiava pela renascença da arte trágica, pondo suas esperanças na produção artística de Richard Wagner, cuja estética, apesar de suas particularidades, pautava-se mais fielmente na concepção schopenhaueriana das artes e da música.

É por conta da entrega da música de Wagner à pulsão vital da Vontade schopenhaueriana que o jovem Nietzsche nutre especial admiração pelo compositor. A ópera de Wagner se distingue nitidamente das demais por dar à música a primazia em relação às outras manifestações artísticas presentes no conjunto de artes em que se fundamenta a ópera, como a arquitetura, a escultura, a atuação cênica e, é claro, a poesia. Segundo Nietzsche, as óperas de até então davam ao texto maior importância que à música, constituindo artes essencialmente apolínias, pelo que a revolução musical operada por Wagner constitui uma revolução dionisíaca, e, afirmando (schopenhauerianamente) o primado da música sobre as demais artes, sua ópera se assemelha à tragédia original.

Para o Nietzsche d'O nascimento da tragédia a ópera wagneriana constituiria, dessarte, o ápice da estética, onde todas as sensações são maximizadas através do ímpeto, da elevação da Vontade, que se alça para além de si, num crescente "mais de Vontade" - que, poderíamos adiantar, é também e a cada vez um "mais de poder" - característico da esfera dionisíaca. Essa consideração, de maximização da Vontade através da arte mais volitiva, a tragédia, é ausente em Schopenhauer; neste, a Vontade se autossuprime na tragédia, nunca se expande. $\mathrm{Na}$ maximização da Vontade que Nietzsche vê na tragédia opera uma das antes chamadas "sutilizas" que distinguem sua abordagem do conceito de Vontade em O nascimento da tragédia da metafísica da Vontade de Schopenhauer. Daí também decorre a esperança por um renascimento

138 | Cad. Nietzsche, Guarulhos/Porto Seguro, v.40, n.2, p. 124-145, maio/agosto, 2019. 
Vontade de tragédia, tragédia da música: Controvérsias entre...

da tragédia autêntica que Nietzsche deposita em Wagner: dado o caráter essencialmente volitivo, dionisíaco, de sua arte, o filósofo vê no músico a possibilidade de uma revolução transvalorante em vistas da Vontade, sempre insaciável e potencializante.

Esse dar-se da Vontade num crescendum, maximizando-se, está diretamente associado à embriaguez dionisíaca, que é precisamente assinalada pela ausência de limites, de comedimento, aspectos propriamente apolíneos. Assim, carente de limitações, dada aos exageros, ao caos, aos transes, aos delírios, enfim, aos ímpetos e anseios mais viscerais, a Vontade aparenta, na consideração nietzschiana, procurar estender-se, via tragédia, para além dos próprios confins da arte, "dionisando" a própria cultura e sociedade. É possível ilustrar isso de outra forma, mais histórica: o culto a Dioniso efetuado através dos ditirambos operava precisamente uma subversão cultural na sociedade grega da época, dado ter-se iniciado por volta do século VIII a.C., quando imperava na sociedade grega o paganismo olímpico. $\mathrm{O}$ deus que vem do Oriente, o deus proscrito, Dioniso, opõe-se ao culto dos deuses clássicos, tradicionais, transvalorando a própria ideia de culto através das dionisíacas; até a figura do templo, fundamental para o culto dos deuses olímpicos, como Apolo, perde seu sentido, porque a liturgia dionisíaca original - e originária - transcende qualquer delimitação geográfico-espacial, bem como desconstrói, do ponto de vista estético, o apreço pelas belas formas, e do ponto de vista moral, o regramento e ortodoxia próprios dos deuses olímpicos, características nitidamente relativas a Apolo. Vendo-se deste ângulo, pode-se ver no próprio surgimento da arte trágica um elemento transvalorante da Vontade, já presente na consideração do jovem Nietzsche, embora ainda não nomeada nestes termos. E, de fato, é bastante sabido que será o caráter transvalorativo da Vontade que virá a constitui-la, no Nietzsche maduro, como Vontade de Potência.

Em retomada à abordagem artística, com efeito, Nietzsche apenas considera a poesia como um elemento importante para a 
Debatin, G.

tragédia à medida que a poesia mesma possua uma musicalidade inerente. De fato, a consideração positiva de uma musicalidade do texto, do poema, é uma contribuição marcadamente wagneriana presente no pensamento do jovem Nietzsche. ${ }^{20}$ Arquíloco, por exemplo, enquanto poeta, apenas é bem visto por Nietzsche devido ao caráter musical próprio da poesia lírica, associado à efervescência dionisíaca imbricada em seu texto, que é ausente da pura contemplação imagética, apolínea, tal como se dá nas artes épica e plástica; ao contrário, os poemas líricos de Arquíloco estão envoltos por um "encantamento dionisíaco-musical" que é capaz de lançar imagens, conjugando-se portanto com o elemento apolíneo, num movimento que, em seu mais elevado grau, são passíveis de "serem chamados tragédias e ditirambos dramáticos" [GT/NT, O nascimento da tragédia 5, KSA 1.44].

As óperas convencionais - bem como as antigas artes épicas e as tragédias tardias, euripedianas -, por outro lado, que se suportariam primeiramente na poesia, e não na música - o que se evidencia, no caso das óperas modernas, pelo recurso do stilo rappresentativo -, são rechaçadas categoricamente por Nietzsche, contravindo uma confessa predileção de Schopenhauer. Considerando manifestações artísticas apolíneas, que negam o dionisíaco, Nietzsche nutre uma bem embasada repulsa pela ópera, embora Schopenhauer enxergue nela uma legítima dualidade de Vontade e representação. Cito Nietzsche:

Acrescento a isso mais uma igualmente clara confirmação da minha consideração, de que a ópera está construída sobre os mesmos princípios que nossa cultura alexandrina. A ópera nasceu do homem teórico, do leigo crítico, e não do artista: é um dos fatos mais estranhos na história de todas as artes. [...] Porque ele não sente a dionisíaca profundeza da música, transforma a apreciação musical em palavras inteligíveis, a retórica tonal da paixão em stilo rappresentativo e em volúpia as artes cantadas; porque ele não é capaz de ver uma visão, ele força o maquinista e o cenógrafo a

20 Veja-se o exposto a respeito de Wagner e da palavra poética na nota 3.

$140 \mid$ Cad. Nietzsche, Guarulhos/Porto Seguro, v.40, n.2, p. 124-145, maio/agosto, 2019. 
Vontade de tragédia, tragédia da música: Controvérsias entre...

se disporem a seu serviço; porque ele não sabe apreender a verdadeira essência do artista, ele conjura diante de si próprio, para satisfazer-se, o "homem artístico primordial", ou seja, o homem que apaixonadamente canta e diz versos (GT/NT O nascimento da tragédia 19, KSA 1.123).

E prossegue, mais adiante:

O que será das eternas verdades do dionisíaco e do apolíneo em tal mistura de estilos, ao modo como eu a determinei como sendo a essência do stilo rappresentativo, em que a música é considerada como serva e o libreto como senhor, em que a música é comparada ao corpo e o libreto à alma, em que, na melhor hipótese, a mais alta meta é uma pintura tonal descritiva, assim como se dava antigamente no novo ditirambo ático, em que a música era completamente alienada de sua verdadeira dignidade, que é ser um dionisíaco espelho do mundo, de modo que a única coisa que lhe resta é imitar, como escrava da aparência, a essência das formas da aparência mesma, a fim de produzir um entretenimento superficial no jogo das linhas e proporções? (GT/NT O nascimento da tragédia 19, KSA 1.126)

Ora, Wagner também foi adepto da filosofia de Schopenhauer, inclusive mais que Nietzsche, dado ter-se mantido, apesar de suas particularidades, fiel à doutrina da Vontade até o final de sua produção artística. O afastamento de Nietzsche e Wagner, portanto, pode não ter se dado apenas pelo alegado por Nietzsche, a saber, que Wagner teria traído a busca dionisíaca do ímpeto vital da Vontade, passando a tratar de conteúdos maximamente apolíneos, sobretudo do Cristianismo, mas por uma mudança ao interno do próprio pensamento nietzschiano, que abandona o idealismo schopenhaueriano e adota uma postura ainda menos essencialista, vendo a Vontade como um ímpeto permanentemente transvalorador. Acena para isso o escrito de Nietzsche em $O$ Caso Wagner: "apenas o filósofo da décadence [Schopenhauer] permitiu que se encontrasse o artista da décadence [Wagner] (WA/CD O caso Wagner, KSA 6, 4.21).

A adesão de Nietzsche a Schopenhauer n'O nascimento $d a$ tragédia é, portanto, coerentemente criticada em sua Tentativa de 
Debatin, G.

Autocrítica. Todavia, julga ter sido muito pior e condenável em seu texto de juventude ver alguma possibilidade de um ressurgimento da tragédia conforme ao espírito originário da música, tal como se dava aos antigos gregos, devotos e adoradores de Apolo e Dioniso.

Mas existe algo muito pior acerca do livro [O nascimento da tragédia], algo que ora me arrependo ainda mais do que ter obscurecido e arruinado minhas premonições dionisíacas com fórmulas schopenhauerianas: a saber, que eu absolutamente estraguei o magnífico problema dos gregos, assim como me suscitara, pela intromissão das coisas modernas! Lamento ter me apegado a esperanças onde nada havia a esperar, onde tudo indicava, com demasiada clareza, para um fim! (GT/NT Tentativa de Autocrítica 6, KSA 1.20).

$O$ renascimento da arte trágica almejado pelo Nietzsche d'O nascimento da tragédia segundo o espírito da música passa, portanto, a demonstrar-se para o Nietzsche maduro como algo impossível, porque não só o próprio espírito da música feneceu, mas qualquer tentativa de retorno às origens por decerto veio a se demonstrar desnecessária. Não havendo mais música autêntica na modernidade, logo, não é mais possível que dela se origine uma nova tragédia. Desse modo, não só a possibilidade de um renascimento do trágico se debilitou, mas também Nietzsche, enquanto filósofo que procura se afastar cada vez mais da força metafísica estável dos sistemas tradicionais. Seu amadurecimento teórico, que o foi distanciando de Schopenhauer, conduziu-o a todas as críticas culturais, históricas e filosóficas que o consagraram como um legítimo e original pensador do século XIX, sob a égide da transvaloração de todos os valores, fazendo de sua metafísica da Vontade de Potência algo por inteiro novo. Poderíamos aventar, portanto e dado o exposto, que, apesar da recorrência formal à metafísica de $O$ mundo como Vontade e Representação em sua leitura da arte trágica, as controvérsias com o pensamento de Schopenhauer que Nietzsche operou em sua caracterização da tragédia e da música serviram como semente para a sua depuração do conceito de Vontade,

142 | Cad. Nietzsche, Guarulhos/Porto Seguro, v.40, n.2, p. 124-145, maio/agosto, 2019. 
que o levou a edificar uma filosofia completamente outra que a de Schopenhauer - e, consequentemente, a seu afastamento de Wagner. Assim, se o seu despontar filosófico foi fortemente influenciado pelo pessimismo schopenhaueriano, seu amadurecer resultou, afinal, num pessimismo maximizado, no pessimismo levado às suas últimas consequências - no niilismo consumado, ao qual damo-nos a liberdade de equiparar aqui, neste contexto, àquilo que é chamado por Nietzsche n'A gaia ciência, de 1882, de "pessimismo dionisíaco" (FW/GC A gaia ciência 370, KSA 3.622): ${ }^{21}$ este já não vê mais solução alguma para a humanidade senão sua própria tragédia; anseia apenas por uma cesura tal em sua décadence que a leve a uma transvalorização total, que dela faça como que se transmutasse a água, insípida, em deleitoso vinho, o pálido chumbo no glorioso ouro, o humano, enfim, em algo trans-humano.

21 Utilizamos aqui a expressão à esteira do sentido que lhe é conferido por Joshua Foa Dienstag, 2001, p. 928-931. 
Debatin, G.

\title{
Will to Tragedy, Tragedy of Music: Disputes between the Young Nietzsche and Schopenhauer
}

\begin{abstract}
The following essay aims to show the theoretical consequences of a latent tension between the notion of tragedy in Nietzsche's The Birth of Tragedy and the Schopenhauerian comprehension of music. This tension occurs not just within the aesthetics interpretations of the mentioned arts by the philosophers cited, but it demonstrates fundamental disparities in the young Nietzsche's thought in respect to the metaphysics of The World as Will and Representation. The hypothesis is that these disparities would culminate in a caesura point between the philosophies of Schopenhauer and Nietzsche, as well in the decline of the friendship of this one with Richard Wagner.
\end{abstract}

Keywords: Tragedy, Music, Will, Nietzsche, Schopenhauer, Wagner.

\section{Referências bibliográficas}

BARROS, Márcio Benchimol. Música como aia da vontade: ensaio sobre a leitura wagneriana de Schopenhauer. Kriterion, Belo Horizonte, n. 125, junho de 2012, pp.179-193.

BEHLER, Ernst. Nietzsche und die Frühromantische Schule. In: Nietzsche-Studien, v. 7, 1978, pp. 59-96.

BURNETT, Henry. O Beethoven-Schrift: Richard Wagner teórico. In: Trans/form/ ação. São Paulo, v. 32, n. 1, 2009, pp. 159-173.

DA SILVA, Luan Corrêa. No espírito da música: para uma tese acerca da síntese trágica em Schopenhauer e Wagner. In: Revista Voluntas: Estudos sobre Schopenhauer. v. 3, n. 1 e 2, 2012, pp. 211-223.

DIAS, Rosa Maria. A influência de Schopenhauer na filosofia da arte de Nietzsche em "O nascimento da tragédia". Cadernos Nietzsche, v. 3, pp. 07-21, 1997.

DIENSTAG, Joshua Foa. Nietzsche's Dionysian Pessimism. In: American Political Science Review. v. 95, n. 4, dezembro de 2001, pp. 923-937.

LIDELL, Henry George; SCOTT, Robert. A Greek-English Lexicon. 6. ed. Oxford: Clarendon Press, 1869.

144| Cad. Nietzsche, Guarulhos/Porto Seguro, v.40, n.2, p. 124-145, maio/agosto, 2019. 
MACHADO, Roberto. Nietzsche e o Renascimento do Trágico. In Kriterion, Belo Horizonte, n. 112, dezembro de 2005, pp. 174-182.

NIETZSCHE, Fiedrich Wilhelm. Sämtliche Werke. Kritische Studienausgabe (Band 1). Herausgegeben von Giorgio Colli und Mazzino Montinari. München/Berlin/ New York: Deutscher Taschenbuch Verlag de Gruyter, 1988.

. Sämtliche Werke. Kritische Studienausgabe (Band 3). Herausgegeben von Giorgio Colli und Mazzino Montinari. München/Berlin/New York: Deutscher Taschenbuch Verlag de Gruyter, 1999.

. Sämtliche Werke. Kritische Studienausgabe (Band 6). Herausgegeben von Giorgio Colli und Mazzino Montinari. München/Berlin/New York: Deutscher Taschenbuch Verlag de Gruyter, 1999.

PLATÃO. A República. 2. v. Tradução de J. Guinsburg. São Paulo: Difusão Europeia do Livro, 1965.

. Teeteto; Crátilo. 2. ed. Tradução de Carlos Alberto Nunes. Belém: Universidade Federal do Pará, 1988.

SCHOPENHAUER, Arthur. O Mundo como Vontade e Representação. Tomo I. Tradução de Jair Barboza. São Paulo: UNESP, 2005.

. Metafísica do Belo. Tradução de Jair Barboza. São Paulo: UNESP, 2003.

SZONDI, Peter. Ensaio sobre o trágico. Tradução de Pedro Süssekind. Rio de Janeiro: Jorge Zahar, 2004.

VATTIMO, Gianni. Diálogos com Nietzsche: ensaios de 1961-2000. Tradução de Silvana Cobucci Leite. São Paulo: Martins Fontes, 2010.

WAGNER, Richard. Beethoven. Leipzig: E. W. Fritzsch, 1870. . Der Kunstwerk der Zukunft. Leipzig: Otto Wigand, 1850.

ZÖLLER, Günter. A música como vontade e representação. Cadernos de Filosofia Alemã. n. 16, pp. 55-80. São Paulo: USP, julho-dezembro de 2010.

Recebido em 28/04/2019

Aceito em 16/06/2019 


\section{ERRATA}

No artigo: DEBATIN, Gabriel. Vontade de tragédia, tragédia da música: Controvérsias entre o jovem Nietzsche e Schopenhauer. Cad. Nietzsche, v. 40, n. 2, p.124-145, 2019. DOI 10.1590/2316-82422019v4002gd

Na afiliação, p. 124, onde se lia:

*Doutorando em Filosofia pela Universidade Federal de Santa Catarina, Florianópolis, SC, Brasil

\section{Leia-se:}

*Professor do Departamento de Ciências Humanas da Universidade Tecnológica Federal do Paraná, Pato Branco, PR, Brasil

**Doutorando em Filosofia pela Universidade Federal de Santa Catarina, Florianópolis, SC, Brasil 